\title{
Andisols Water Retention Under Peasant Oil Palm Plantation
}

\author{
Bujang Rusman", Agustian", Aprisal ${ }^{\#}$, Syafrimen Yasin ${ }^{\#}$ \\ \# Departement of Soil Science, Faculty of Agriculture, University Andalas, Padang, Indonesia \\ E-mail: bujang.rusman@yahoo.com
}

\begin{abstract}
Available water soil is one of the critical factors that influence oil palm growth and production. This research used field survey method. Soil samples were taken in the field and then analyzed in the laboratory using the membrane plate apparatus for assessment of the filed capacity and the permanent wilting. This research aimed to obtain data about water retention variability of Andisols in oil palm plantation of peasants on various age levels of oil palm in Pasaman sub-district, West Sumatera. The advantage of this research was to find out the effect of different age levels of oil palm on soil water retention and other physical soil properties in Andisols. This research identified water retention of the soil was between 21.2-42.7\% volume with the bulk density (BD) was between $0.31-0.83 \mathrm{~g} / \mathrm{cc}$. The results showed that there is no significant difference between the oil palm ages (5-10 years, 10-15 years, and above 15 years) on either the soil water retention or the soil bulk density for both the topsoil $(0-20 \mathrm{~cm})$ and the subsoil $(20-40 \mathrm{~cm})$. This research indicated that there is no effect of the oil palm age on the soil bulk density, field capacity, permanent wilting point, and plant available water. This research suggested that the soil should be saturated with high water content since West Sumatera has very high rainfall intensity so that the situation can be an advantage for oil palm growth over the years.
\end{abstract}

Keywords - Andisols; available water; oil palm; soil water retention.

\section{INTRODUCTION}

The Indonesian archipelago encompasses one of the most active volcanic areas in the world, surrounded by 128 active volcanoes. On the island of Sumatera, there are 31 volcanoes, situated mostly along the Barisan Mountain Range [1].Most of the Indonesian Andisols are among the most productive soils. The soils are being cultivated with both annual and perennial of upland crops, such as tea, coffee, cacao with quite high productivity. The areas in the vicinity of volcanoes are also well known as the horticultural center and support more than $50 \%$ of the Indonesian people needs [2]. Various kinds of soils can be formed from volcanic ash based on the individual set of soil formation factors at different sites. Among these soils, Andisols show unique properties mostly due to abundant noncrystalline materials, such as allophane, imogolite, Al-humus complexes, and ferrihydrite. Highly porous structures made of aggregated no-crystalline Andisols material have a light and fluffy nature, accommodating large amounts of both plantavailable and hygroscopic water [3]. These soils have unique and distinct properties with low bulk density, high water retention, high permeability, stable structure, high amount of current $\mathrm{Al}$ and $\mathrm{Fe}$, variable charge, and high phosphate fixation [4].

The potential of natural resources in the region of North Sumatera is enormous with a vast plantation reaches $15.2 \%$ of Indonesia palm oil plantation. Crude Palm Oil (CPO) reach $7.9 \%$ of total Indonesia palm oil export [5]. Deforestation for oil palm plantation in West Sumatera conducted since last few decades [6]. Deforestation for tree cash crop plantation, such as oil palm, rubber, and cacao agro-forest in the tropics results in sharp decreases in soil organic carbon (SOC) stocks. Much of this carbon lost through carbon dioxide (CO2) emission and leaching [7]. The land use change from native forest to pasture exposed the soil to higher mechanical stresses leading to soil compaction. Since soil shrinkage during drying, the bimodal character of the water retention curve changed only the macropore range. Meanwhile, the textural range remained constant when native forest (NF) changed to P50 (permanent pasture for over 50 years). The land use change affected the saturated hydraulic conductivity of the soil [8].

Farming in sloping areas is not the only risk for the erosion, but also problematic to the fertility [9]. Soil characteristics influence essential soil functions, such as: (1) Moderating and partitioning water and solute movement and their redistribution and supply to plant, (2) Storing and cycling nutrients, (3) Filtering, buffering, immobilizing and detoxifying organic and inorganic materials, (4) Promoting root growth, and (5) Promoting resistance to erosion [10]. Bulk density (BD) of Andisols in Indonesia was highly varied that was $0.37-0.90 \mathrm{~g} / \mathrm{cm}^{3}$. This low BD of Andisols depend on amorphous mineral-dominated by this soil. Since Andisols dominated by amorphous mineral, the soil has 
many micropores with inter-aggregates of the allophane [11]. Characterisation of Available Water Capacity (AWC) of soil is essential for assessing the soils physical status and quality. The availability of soil moisture would control the rates of evaporation and transpiration and have a significant impact on climate. It also manages hydrologic processes for instance; groundwater recharging, infiltration and surface runoff. Soil water content is one of the soil factors for plant growth, influencing carbon allocation, nutrient cycling, and the rate of photosynthesis [12].

Soil water storage is commonly measuring at different moisture tensions, that is $\mathrm{pF}$ (potential force) $1,2,2.54$, and 4.2. Water storage of soils from Mt. Merapi measured at $\mathrm{pF}$ one ranges between 53 to $72 \% \mathrm{w} / \mathrm{w}$ or between 25 to 209 $\mathrm{mm}$ while materials of Mt. Pasaman have water storage between 53 to $72 \% \mathrm{w} / \mathrm{w}$ or 53 to $162 \mathrm{~mm}$ [2]. Based on the previous research on the arid region in Ivory Coast, West Africa, and India, the oil palm plantation was interfered the groundwater for other crops outside of the farm [13]. Furthermore, it is explained that the groundwater draining by oil palm is big in which one oil palm plant can absorb 20 to 40 liters water per day and can also suck up the water up to the depth of 5.2 meters.

Available water is one of the essential components for the growth and development of oil palm in Andisols. The water absorbed by the plant is the water located in soil pores. Every type of soil has a different distribution and pore size, which will affect the water content in the soil by considering the high water consumption of oil palm. Some research results, for example in the Ivory Coast and India or arid regions, show that due to the high water consumption, it can cause the water deficit in an area, especially in the dry season.

The connection between soil, water, and plants is known as a concept of available water for plant growth, in which water content is the range of water content in the soil that is needed by the plants [14]. This condition is strongly related to the ability of the ground to hold water (water retention). The basic principles of available water for the plant are related to the provision of water in sufficient and balanced quantities for plant growth in which the soil water content is between field capacity $(2.54 \mathrm{pF})$ and permanent wilting point ( $\mathrm{pF}$ 4.2).

This research focused on analyzing the effect of age of oil palm on the physical properties of the soil and the diversity of soil water retention on Andisols in Pasaman sub-district, West Sumatera, Indonesia.

\section{MATERIAL AND METHODS}

\section{A. Research Site}

This research was conducted in the oil palm plantation of a peasant in Pasaman sub-district, West Pasaman district and the physical analysis of soil identified at Soil Laboratories of Faculty of Agriculture, Andalas University and Soil Centre Research Bogor. This research conducted from January up to May of 2016.

\section{B. Research Methods}

The research methods were through a field survey. Soil samples were taken in the field and then analyzed in the laboratory. Soil sampling points were determined by overlaying four types of the map; those were an official map of Pasaman Region, visual earth map of Indonesia, soil and land unit map, and Shuttle Radar Topography Mission (SRTM). Geographical position of sampling location in

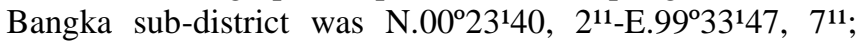
N.OO ${ }^{\circ} 23^{149}$, $0^{11}$-E.99 $33^{14} 48,9^{11}$; and N.00 $23138,22^{11}$ E.00 $23^{13} 3,2^{11}-E .99^{\circ} 33^{148}, 5^{11}$ with elevation 292-311 meter above sea level (masl). Meanwhile, soil physical analysis has conducted at soil laboratory Faculty of Agriculture, Andalas University, and soil physics laboratory Soil Centre Research Bogor.

The soil sample was taken based on three groups of oil palm age, at age range from 5-10 to 10-15 and above 15 years on sloping land that is more than $15 \%$. In the point of each soil sample, the undisturbed sample taken by using soil cores in 0-20 cm and $20-40 \mathrm{~cm}$ depth, in which on each layer, two samplings were chosen. Therefore, in each observation place, there were four soil core samples with total amount 12 samples and soil analysis for soil profile sample.

Soil core sample was taken to determine the bulk density (BD), particle density (PD), total pore space by using gravimetric method [15] and available water content by using pressure plate apparatus method [16]. For soil texture analysis, the sample took from the composite soil in depth of $0-20 \mathrm{~cm}$ and $20-40 \mathrm{~cm}$. The soil texture analyzed by using sieve and pipette method based on Stokes Law, and the texture class determined by using the textural triangle.

\section{RESULT AND DISCUSSION}

\section{A. Bulk density and total pores space}

The effect of soil physical properties analysis especially the bulk density (BD), particles density (PD), and total pore space is presented in Table 1.

TABLE I

BULK DENSITY (BD) AND TOTAL PORE SPACE IN THE OIL PALM PLANTATION OF THE PEASANT IN PASAMAN SUB-DISTRICT, WEST SUMATERA.

\begin{tabular}{|l|l|l|l|l|}
\hline $\begin{array}{l}\text { Age of } \\
\text { palm } \\
\text { tree } \\
\left(\begin{array}{l}\text { years } \\
\text { old })\end{array}\right.\end{array}$ & $\begin{array}{l}\text { Soil layer } \\
(\mathrm{cm})\end{array}$ & $\begin{array}{l}\text { Particle } \\
\text { Density } \\
(\mathrm{g} / \mathrm{cc})\end{array}$ & $\begin{array}{l}\text { Bulk } \\
\text { Density } \\
(\mathrm{g} / \mathrm{cc})\end{array}$ & $\begin{array}{l}\text { Total pore } \\
\text { space } \\
(\% . \mathrm{vol})\end{array}$ \\
\hline $5-10$ & $0-20$ & 2.23 & 0.57 & 74.35 \\
\hline & $20-40$ & 2.23 & 0.52 & 77.00 \\
\hline $10-15$ & $0-20$ & 2.34 & 0.69 & 70.4 \\
\hline & $20-40$ & 2.46 & 0.79 & 67.90 \\
\hline$>15$ & $0-20$ & 2.34 & 0.67 & 71.4 \\
\hline & $20-40$ & 2.42 & 0.81 & 66.4 \\
\hline
\end{tabular}

Table 1 shows that the value of soil bulk density on the topsoil $(0-20 \mathrm{~cm})$ was ranging from 0.52 to $0.88 \mathrm{~g} / \mathrm{cc}$ (with $0.36 \mathrm{~g} / \mathrm{cc}$ difference). The soil particles density was around 2.08 to $2.48 \mathrm{~g} / \mathrm{cc}$ (the with $0.40 \mathrm{~g} / \mathrm{cc}$ difference). Whereas, on the subsoil, the bulk density was around 0.51 to $0.83 \mathrm{~g} / \mathrm{cc}$ (with $0.32 \mathrm{~g} / \mathrm{cc}$, difference), and the particles density was around 2.14 to $2.62 \mathrm{~g} / \mathrm{cc}$ (with $0.48 \mathrm{~g} / \mathrm{cc}$ difference). On the other hand, the total pore space of topsoil $0-20 \mathrm{~cm}$ was 64.5 
to $77.8 \%$ volume (with $13.3 \%$ difference), and subsoil 20 $40 \mathrm{~cm}$ was around 62.9 to $80.6 \%$ volume (with $17.7 \%$ difference). The soil bulk density, the particles density, and the total pore space between the topsoil and subsoil in Andisols under oil palm crops from three different ages (510 years, $10-15$ years, and above 15 years) strictly related to the texture variability. The soil texture influenced by the various types of minerals from a volcano eruption. Therefore, the bulk density and the total pore space also varied. Additionally, the soil $\mathrm{BD}$ and the entire pore were also affected by the soil organic matter content. The effect of oil palm age in Pasaman sub-district on some soil physical properties especially bulk density and total pore space were not significant (Table 3).

Based on bulk density criteria assigned by Soil Centre Research [17], the bulk density of Andisols Pasaman classified into low standards under oil palm of 10-15 and above 15 years old, and medium under 5-10 years old. Meanwhile, for total pore space, based on the criteria, it was classified as high class, except for the land that planted with oil palm at the age of 5-10 years old, and it was rank into the medium level. Based on a research result, matured Andisols typically have a low bulk density of 0.9 or lower and are lowest among mineral soils [3]. The low bulk density of Andisols can easily be recognized if one picks up and airdried soil clod by hand. Only organic soils or organic horizons have high bulk densities values than Andisols. The low bulk density is due to high porosity caused by welldeveloped aggregate structures made of noncrystalline minerals, such as allophane.

Based on the mentioned data, it can be concluded that there are effects of oil palm at the age of 5-10 years old if it is compared with 10-15 years old and above 15 years old plant on the bulk density and total pore space in Andisols Pasaman. For the oil palm at the age of under 10 years, the oil palm canopy has reached $100 \%$ of its growth to cover soil surface. When it is related to rainfall, and its high intensity in this area, the kinetic energy generated by precipitation and its high volume can cause soil compaction process in the open field. Besides, the age factor of the plant, the diversity of the value of bulk density and total pore space of Andisols Pasaman was also determined by texture, organic matter content and clay allophane mineral derived from the tuff volcanic ash of the Pasaman volcano eruptions. The bulk density values of the soils are less than $0.9 \mathrm{Mg} \mathrm{m}^{-3}$, satisfying the andic soil properties requirement. The BD of the A horizons of the southern slope soils of Mt. Merapi ranges from 0.73 to $0.89 \mathrm{Mg} \mathrm{m}^{-3}$, while for the northern slope soils it ranges from 0.63 to $0.88 \mathrm{Mg} \mathrm{m}^{-3}$. The bulk density value of the $\mathrm{B}$ horizons is slightly lower than those of the surface horizons; the amount is $0.58-0.86 \mathrm{Mg} \mathrm{m}-{ }^{3}$. Allophane is responsible for the lower bulk density in the $\mathrm{B}$ horizons as it is more abundant in B horizons than in the top soils. Bulk density tends to be also lowered by organic matter [2].

Total pore space is the number of all pores in a soil volume that is expressed in the percentage by volume (\% .volume). The pore arrangement and size will determine the level of soil aeration and water holding capacity or provide capabilities. The pore size of available water storage is between 0.2 to 9 microns, or by the pull of 0.3 to 15 atmospheres [18]). However, many experts reveal that available water is located between the pull of the soil matrix, 0.1 to 15 atmospheres or between $\mathrm{pF} 2.0$ to $\mathrm{pF} 4.2$. This pore is equivalent to the pore size between 0.2 to 30 microns. The orifice of available water storage is sometimes as a barrier on sandy soil. The pore size that is greater than 30 microns is equivalent to $\mathrm{pF}=2.0$, this pore is usually filled with air and called aeration pore or fast drainage pore [19].

Soil bulk density is inversely related to total soil pore space. Sandy soils [20], soils having a lower percentage of entire pore space, have higher bulk density than clay textured soils. Although the sandy soil has less pore space, the air and water movement were very fast because of the predominance of macropores. Furthermore, the soil texture is significant to be noted and it will determine the soil properties because of its considerable influence on the rate of water infiltration into the soil, water storage, the natural process of tillage, soil aeration and fertilization [15].

\section{B. Soil water retention}

The result of field capacity and plant available water determination of Andisols under three ages of oil palm crops is shown in Table 2.

TABLE II

WATER RETENTION ANALYSIS IN THE OIL PALM OF A PEASANT IN PASAMAN SUB-DISTRICT, WEST SUMATERA.

\begin{tabular}{|c|l|l|l|l|l|}
\hline $\begin{array}{c}\text { Age } \\
\text { (years) }\end{array}$ & $\begin{array}{c}\text { Soil } \\
\text { layer } \\
(\mathrm{cm})\end{array}$ & $\begin{array}{c}\text { Water } \\
\text { content } \\
(\% . v o l)\end{array}$ & $\begin{array}{c}\text { Water } \\
\text { retention } \\
(\mathrm{pF} 2.54) \\
(\% . v o l)\end{array}$ & $\begin{array}{c}\text { Water } \\
\text { retention } \\
(\mathrm{pF} 4.2) \\
(\% . v o l)\end{array}$ & $\begin{array}{c}\text { Plant } \\
\text { available } \\
\text { water } \\
(\% . v o l)\end{array}$ \\
\hline $5-10$ & $0-20$ & 60.65 & 58.05 & 23.25 & 34.80 \\
\hline & $20-40$ & 58.75 & 55.95 & 16.00 & 39.95 \\
\hline $10-15$ & $0-20$ & 52.85 & 50.05 & 23.20 & 26.85 \\
\hline & $20-40$ & 50.55 & 50.10 & 25.25 & 24.85 \\
\hline$>15$ & $0-20$ & 48.65 & 45.40 & 22.15 & 23.25 \\
\hline & $20-40$ & 55.95 & 48.80 & 25.30 & 23.50 \\
\hline
\end{tabular}

Table 2 indicates that the value of field capacity $(\mathrm{pF} 2.54)$ on topsoil $(0-20 \mathrm{~cm})$ was from 43.2 to $58.7 \%$ volume (with $13.5 \%$ difference) and on subsoil $(20-40 \mathrm{~cm})$ was from 39.6 to $62.7 \%$ volume (with $23.1 \%$ difference). Meanwhile, the water content at permanent wilting point condition $(\mathrm{pF} 4.2)$ for layer $0-20 \mathrm{~cm}$ and $20-40 \mathrm{~cm}$ shows the value was between 18.2 to $27.3 \%$ volume (with $9.1 \%$ difference). The effect of age oil palm in Pasaman sub-district to water content, field capacity ( $\mathrm{pF} 2.54$ ), permanent wilting point ( $\mathrm{pF} 4.20$ and plant available water are shown not significant (Table 3).

The variation of the water content on topsoil $0-20 \mathrm{~cm}$ (with $23.1 \%$ difference) was mostly determined by the soil organic matter content, texture, and clay mineral types. These three factors positively correlated to plant available water. The value of plant available water on topsoil (0-20 $\mathrm{cm}$ ) was between 17.9 to $35.4 \%$ (with $17.5 \%$ difference) and on subsoil $(20-40 \mathrm{~cm})$ was between 13.5 to $44.5 \%$ volume (with $31.0 \%$ difference).

The soil properties Pasaman sub-district is Andisols on the $0-20 \mathrm{~cm}$ of topsoil which majority is planted by various ages of oil palms, around 5 to 15 years. While for the 20$40 \mathrm{~cm}$ soil layer, the available plant water belonged to 
medium (10-15\%) class. The overview of the available water content has a positive correlation with a water content of field capacity ( $\mathrm{pF}$ 2.54). Based on previous research, Andisols, which are dominated by non-crystalline allophonic minerals, had the high water-holding capacity at $-1500 \mathrm{kPa}$ [12]. The soils also showed the highest water storage capacity (29\%), the highest volumetric water content at field capacity (56\% in average), and the lowest volumetric water content at wilting point (27\%) [12]. Entisols and Inceptisols which have loamy texture also show high water retention. The most moderate water retention is Entisols which are dominated by sandy materials.

TABLE III

LEAST SQUARES LINEAR REGRESSION RESULTS BASED ON SOIL PHYSICAL PROPERTIES AND WATER RETENTION CHANGES OF DIFFERENT PLANT AGE, IN PASAMAN SUB-DISTRICT

\begin{tabular}{|l|l|l|l|l|}
\hline No & Variable & Reg.Coef & Std.Error & Sig.Value (in) \\
\hline 1 & $\begin{array}{l}\text { Bulk } \\
\text { density } \\
\text { (g/cc) }\end{array}$ & 0.05000 & 0.04041 & $0.4328>0.05$ \\
\hline 2 & $\begin{array}{l}\text { Total } \\
\text { pore } \\
\text { space } \\
\text { (\%.vol) }\end{array}$ & -1.47000 & 1.42606 & $0.4903>0.05$ \\
\hline 3 & $\begin{array}{l}\text { Water } \\
\text { content } \\
(\% . v o l)\end{array}$ & -6.00000 & 1.03923 & $0.1092>0.05$ \\
\hline 4 & $\begin{array}{l}\text { Field } \\
\text { capacity } \\
\text { (pF 2.54) } \\
(\% . v o l)\end{array}$ & -6.32500 & 0.96706 & $0.0966>0.05$ \\
\hline 5 & $\begin{array}{l}\text { Permane } \\
\text { nt wilting } \\
\text { point (pF } \\
4.2) \\
(\% . v o l)\end{array}$ & -0.55000 & 0.28868 & $0.3077>0.05$ \\
\hline 6 & $\begin{array}{l}\text { Plant } \\
\text { available } \\
\text { water } \\
(\% . v o l)\end{array}$ & -5.77500 & 1.25574 & $0.1363>0.05$ \\
\hline Reg.coef.=Regression Coefficient, Std.Error=Standard error, & & & \\
\hline
\end{tabular}

Remark: Reg.coef.=Regression Coefficient, Std.Error=Standard error, Sig. Value=Significant value

Soil water content at field capacity and permanent wilting point and available water in the soil will vary and determined by many factors and interactions and the interrelations between the classes of soil texture, organic matter content, the depth of the water table which is related to the position of land slope [16]. For example, soil with silty clay texture, the variation of the plant available water is between 0.13 to $0.19 \%$ volume and the field capacity water content is between 0.30 to $0.42 \%$ volume. While for soil with silty clay loam texture, the variation of plant available water is between 0.13 to $0.18 \%$ volume and the field capacity water content is between 0.30 to $0.37 \%$ volume. It was found that the Andisols in Pasaman sub-district had 23.50-39.95\% available water content.

Andisols has typical physical properties, and it was assumed that such features are closely related to the high content of allophane. Allophane is composed of hollow spheres in diameter 35-50A. This mineral has many holes that allow water molecules in and out [19]. Based on these properties, Andisols has high soil water content or water retention. Since it has the hollow soil texture, this soil is vulnerable to erosion.

The data groundwater absorption $(\mathrm{pF})$ or water retention, practically it is essential in delineating relationships between energy retention that affects vital processes in the soil and water movement and nutrient uptake for oil palms, like the vast dissolution of fertilizer that is given to oil palms.

The data of soil physical properties and water levels shown in Table 1 and Table 2 are beneficial for answering a lousy phenomenon on oil palm plantation. These data are expected to come out the aspect of water deficit on agricultural lands planted with oil palms, especially at Ultisols and Oxisols in an arid region. Conversely, in particular, for Andisols in Pasaman sub-district, its unique characteristics are dominated by amorphous allophane clay mineral derived from volcanic ash of Talamau Mountain and spread on the wet tropics in the west coast of the Sumatra Island with annual rainfall between $3500-4000 \mathrm{~mm}$ per year. It shows that the phenomenon of soil water deficit on Andisols in Pasaman sub-district has not been observed yet due to the influence of oil palm cultivation at the age of 5-10 years, 10-15 years and over 15 years.

Availability of data and information about physical properties of soil is essential as a database for commodity development of oil palm plantation in the future. Among the data needed especially for Andisols in Pasaman sub-district are available to water (AW), bulk density (BD), texture and organic matter content of the soil. The physical of soil properties and available water content are one of the variables to determine the quality of the land, beside climatic factors, soil fertility, and topography.

The uniqueness of Andisols characteristics, especially Andisols Pasaman sub-district, is that it has andic characters with low soil bulk density (BD) and high soil organic matter content and $\mathrm{P}$ retention. This is due to the soil mineral which is dominated by allophane complex or Al-humic derived from ash volcanic material or bursts of volcanic eruptions from Pasaman volcano. The volcano materials were rich in $\mathrm{Fe}$ and $\mathrm{Al}$ crystal mineral. Texture with a moderate size is dominated by loam texture and porous soil which is distributed on the wet tropics with 3500-4000 mm rainfall per year. The uniqueness and characteristics of this Andisols provide variability or diversity of soil physical properties and the water content at a few pF level [17]

Why do the Andisols that has been planted by oil palm for 15 years still have a high content of available water and low bulk density? It was caused by the clay texture content (smooth) with amorphous clay minerals (allophane) which had a more significant water holding ability than the sandy soil (coarse) and crystalline clay kaolinite and montmorillonite. This ensued because of the high adsorptive surface area of clay mineral, so the capacity of storing water and organic material is more significant. The intensity of land use cannot change the soil shrinkage magnitude only the structural shrinkage and large pores [21]. However, the cycles of previous wetting/drying cycles depend on the land use. This phenomenon influences pore shrinkage capacity 
significantly and soil shrinkage behaves differently. Under natural conditions, Andisols have a high soil water infiltration capacity, a consequence of their active structural development and stability. However, due to the strong influence of the mineral type and the high organic matter content on their structural properties, they are highly susceptible to changes in environmental conditions. Based on the analysis, it can be summarised that the change of soil properties is a consequence of the land use change, from the forest to specific vegetation.

\section{CONCLUSIONS}

The results of this research indicate that the Andisols in Pasaman sub-district with a slope more than $15 \%$, planted with oil palm at age 10-15. Afterward, over 15 years, the had medium bulk density (BD) and high total pore space. Whereas, the land under oil palm at age 5-10 years had medium bulk density and entire pore space. Water retention of Andisols in Pasaman sub-district, planted with oil palm at the age of 10-15 and above 15 years old, had a very high class of available water (AW) and only on the land planted with palm at age 5- 10 years old, the water availability is high-class. Based on the land evaluation from soil physics aspect at the peasant oil palm plantation in Andisols in Pasaman sub-district, it can be concluded that there is no impact of oil palm at age 10-15 and above 15 years on the soil water deficit phenomenon. There is no correlation between the crop ages with water consumption. Andisols has a unique characteristic which consists of high content of allophane mineral, hollow spherules. This unique characteristic has a high absorbency of water from soil saturation

\section{ACKNOWLEDGMENT}

This research was funded by Andalas University Research Center under contract number:51/UN.16/HKRGB/LPPM/ 2016.

\section{REFERENCES}

[1] Van Bemmelen RW. 1970. The geology of Indonesia, vol I A. The Hague: Martinus Nijhoff.

[2] Fiantis D, Hakim N, Van Ranst E. 2005. Properties and utilization of Andisols in Indonesia. Special Review. JIFS,2:29-37 (2005).

[3] Nanzyo M .2002. Unique properties of volcanic ash soils. Graduate School of Agricultural Science. Tohoku University. Japan: 99-112.

[4] Shoji S, Nanzyo M, Dahlgren R. 1993.Volcanic Ash Soils. Elsevier. Amsterdam. 288 p.
[5] Juliza H, Sukardi S,Ani S,Anas MF,Sugiarto S.2015. Optimization of palm oil plantation revitalization in North Sumatera, Indonesia. Ijaseit Vol.5 (2015). No.6. 460-468. ISSN.2088-5334.

[6] Yasin S, Yulnafatmawita. 2007. Effect of slope position on physicochemical characteristics of soil under oil palm plantation in the wet tropical area, West Sumatera Indonesia. Soil science Depart, Fac. of Agriculture, Andalas University, Padang.

[7] Van Straaten O, Corre MD, Wolf K, Tchienkoua M, Cuellar E, Matthews RB, Veldkamp E (2015). Conversion of lowland tropical forests to tree cash crop plantations loses up to one-half of stored soil organic carbon. Cross Mark. August 11, 2015. Vol. 112. No.32

[8] Dorner J, D Dec, X Peng, R Horn. 2010. Effect of land use change on the dynamic behavior of structural properties of an Andisols in southern Chile under saturated and unsaturated hydraulic conditions. Geoderma 159 (2010) 189-197

[9] Yulnafatmawita, Hermansah. 2016. Chemical characteristics of soils based on topo sequences under wet tropical area Bukit Sarasah, Padang. Ijaseit Vol. 6 (2016) No.2. ISSN-2088-5334.

[10] Karlen DL, Mausbach MJ, Doran JW, Cline RG, Harris RF, Schuman GE. 1997. Soil quality: a concept, definition, and framework for evaluation. Soil Sci.Soc.Am. J.61. 4-10.

[11] Sukarman dan Ai Dariah (2014). Tanah Andosol di Indonesia. Karakteristik, potensi, kendala dan pengelolaannya untuk pertanian. Balai Besar Penelitian dan Pengembangan Sumberdaya Lahan Pertanian. Kementerian Pertanian. ISBN 978-602-8977-84-5.

[12] Hong SY, Minasny B, Han KH, Kim Y, Lee K. 2013. Predicting and mapping soil available water capacity in Korea. Korean Journal of Soil Science and Fertilizer. PeerJ: 1-12.

[13] Kallarackal., P. Jeyakumar., S.J. George. 2004. Water use of irrigated oil palm at three different arid locations in peninsular India. Journal of Oil Palm Research (Malaysia). 16: 45-53.

[14] Utomo M., Sudarsono. Rusman B, Wawan., Sabrina T, dan Lumbanraja J. 2016. Ilmu Tanah. Dasar-Dasar dan Pengelolaan. Penerbit Kencana Prenadamedia Group.Jakarta

[15] Brady, N. C., and R. R. Weil. 2008. The nature and properties of soils. Pearson International . Lembaga Penelitian Tanah. 1979. Penuntun analisa fisika tanah. Badan Penelitian dan Pengembangan Pertanian. Departemen Pertanian. Bogor. 58 hal.

[16] Gardiner, D.T., R.W.Miller. 2008. The soil in our environment. Eleventh Edition. Pearson Prentice Hill. Upper Saddle River, New Jersey Columbus, Ohio.

[17] Lembaga Penelitian Tanah. 1979. Penuntun analisa fisika tanah. Badan Penelitian dan Pengembangan Pertanian. Departemen Pertanian. Bogor. 58 hal.

[18] De Boodt , L De Leenheer. 1958. Soil structure index and plant growth. International Symposium on soil structure. Ghent.

[19] Kurnia, U., F. Agus.,A. Djunaedi, dan S. Marwanto. 2006. Sifat fisik tanah dan metode analisisnya. Balai Besar Litbang Sumberdaya Lahan Pertanian. Litbang Sumberdaya Lahan Pertanian. Departemen Pertanian.

[20] Tan KH. 1998. Andosol. Program Studi Ilmu Tanah .Program Pasca Sarjana, Universitas Sumatera Utara, Medan. 75 hal.

[21] Dorner J, D.Dec, X.Peng, R Horn. 2009. Change of shrinkage behavior of an Andisols in southern Chile: Effects of land use and wetting/drying cycles. Soil \& Tillage Research 106 (2009) 45-53.

[22] Neris J, Jimenez C, Fuentes J, Morillas G, Tejedor M. 2012. Vegetation and land-use effects on soil properties and water infiltration of Andisols in Tenerife (Canary Islands, Spain). Catena 98 (2012) 55-62. 